\title{
MODELLING THE IMPACT OF TROPOSPHERIC OZONE CONTENT ON LIGHT- AND PHEROMONE-TRAPPED INSECTS
}

\author{
LADÁNYI, M. ${ }^{1}{ }^{*}$ - NOWINSZKY, L. $^{2}-\mathrm{KISS}, \mathrm{O}^{3}{ }^{3}$ - PUSKÁS, $\mathrm{J}^{2}{ }^{2}$-SZENTKIRÁLYI, F. ${ }^{4}-$ \\ BARCZIKAY, G. ${ }^{5}$ \\ ${ }^{I}$ Corvinus University of Budapest, Dept. of Mathematics and Informatics, \\ H-1118 Budapest Villányi Street 29., Hungary \\ ${ }^{2}$ University of West Hungary, Savaria University Centre, \\ H-9700 Szombathely Károlyi G. Square 4., Hungary \\ ${ }^{3}$ Eszterházy Károly College, Dept. of Zoology, H-3300 Eger Eszterházy Square 1., Hungary \\ ${ }^{4}$ Plant Protection Institute of the Hungarian Academy of Sciences, Centre for Agricultural \\ Research, Dept. of Zoology, H-1022 Budapest Herman Ottó Street 15., Hungary \\ ${ }^{5}$ County Borsod-Abaúj-Zemplén Agricultural Office of Plant Protection and Soil Conservation \\ Directorate, H-3917 Bodrogkisfalud Vasút Street 22., Hungary \\ *Corresponding author \\ e-mail: marta.ladanyi@uni-corvinus.hu \\ (Received $3^{\text {rd }}$ May 2012; accepted $17^{\text {th }}$ October 2012)
}

\begin{abstract}
The study investigates the effect of the tropospheric ozone content on the relative catch of European Vine Moth (Lobesia botrana Den. et Schiff.), Spotted Tentiform Leafminer (Phyllonoricter blancardella Fabr.), Setaceous Hebrew Character (Xestia c-nigrum L.), Latticed Heath (Chiasmia clathrata L.), April Beetle (Rhizotrogus aequinoctialis Herbst) and Ecnomus tenellus Rambur trapped between 2004 and 2011 in Hungary. In order to describe the empirical connection between the ozone content of the air and the relative number of trapped insects, we introduce some nonlinear regression models of the same general model as origin. We show that elevated ozone content of air stimulates basically two different kinds of response in flying activity of insects.
\end{abstract}

Keywords: ozone, insect, trap, Hungary, nonlinear regression models

\section{Introduction}

According to the Fourth Assessment of the Intergovernmental Panel on Climate Change (IPCC, 2007) tropospheric ozone $\left(\mathrm{O}_{3}\right)$ is the third most important anthropogenic contributor to greenhouse radiative forcing (3-7\%) with a medium level of scientific understanding. Summer daytime ozone concentration correlates strongly with temperature. Tropospheric ozone is expected to increase at 40-60\% up to the end of the $21^{\text {st }}$ century which is linked to air quality and climate change (Meleux et al., 2007).

Tropospheric ozone was first determined to be phytotoxic to grapes in southern California in the 1950s (Karnosky et al., 2007). Ozone is a harmful agent causing oxidative stress on plants which may vary in their tolerances. Changes in agricultural productivity can be, in one hand, the result of direct effects of ozone at the plant level, or, in the other hand the consequence of indirect effects at the system level, for instance, through shifts in nutrient cycling, crop-weed interactions, insect pest occurrence, and plant diseases (Fuhrer, 2003). 
The tropospheric ozone $\left(\mathrm{O}_{3}\right)$ concentration has been monitored in Hungary at $\mathrm{K}$ puszta $\left(46^{\circ} 58^{\prime} \mathrm{N} 19^{\circ} 35^{\prime}\right)$ by the Hungarian Meteorological Service (HMS) since 1996, with 10 minutes averaged ozone concentration detected. Since 2004 the monitoring system was extended to 10 stations in Budapest and 37 ones in other locations throughout Hungary. The ozone content of the air is usually measured in ppm, ppb, $\mu \mathrm{g}$ or $\mathrm{mg}$ units $\left(0.1 \mathrm{ppm} \mathrm{O}_{3}\right.$ by weight $=100 \mathrm{ppb} \mathrm{O}_{3}$ by weight $=200 \mu \mathrm{g} \mathrm{O} / \mathrm{m}^{3}=0.2 \mathrm{mg}$ $\left.\mathrm{O}_{3} / \mathrm{m}^{3}\right)$.

The highest ozone levels occur typically in towns and cities, however, in some situations high ozone content have been measures in locations even hundreds of kilometres far away from the emission sources. Elevated ozone concentration is detected usually in summer months - from May until August - caused by bright sunshine and high temperature, or sometimes in early spring, mainly in March (Ferenczy, 2012).

Kalabokas and Bartzis (1998), Kalabokas (2002), Kalabokas et al. (2000) Papanastasiou et al. $(2002,2003)$ as well as Papanastasiou and Melas (2006) in Greece have studied the daily and monthly ozone content fluctuation. The ozone content is usually higher from noon to evening and decreasing from evening to dawn. It hits its lowest point in the dawn hours and begins to rise again in the early morning. However, according to Juhász et al. (2006) the ozone content of the atmosphere is occasionally still significantly high during the night.

Nevertheless, all external circumstances, including the various meteorological features (wind direction, wind speed, temperature, UV-radiation etc.) should also be considered in order to explain extreme ozone content values (Puskás et al., 2001).

In Hungary, according to the measurements of the Hungarian Meteorological Service (www.met.hu) the health protection threshold of ozone (according to the European Committee Directive, the highest 8-hour mean within one day is higher than $120 \mu \mathrm{g} / \mathrm{m}^{3}$, http://www.eea.europa.eu/maps/ozone/legislation/eu-legislation-and-directives) are exceeded often in summer, the population information threshold $\left(180 \mu \mathrm{g} / \mathrm{m}^{3}\right.$ for the mean value over one hour) are exceeded very rarely while the population warning threshold $\left(240 \mu \mathrm{g} / \mathrm{m}^{3}\right.$ for the mean value over one hour) are extremely rarely.

\section{Review of literature}

\section{Ozone in plant - insect relations}

DeLucia et al. (2005) tested the hypothesis that changes in tropospheric chemistry affect the relationship between plants and insect herbivores by changing leaf quality. Their data suggest that global change in the form of elevated levels of $\mathrm{CO}$ and $\mathrm{O}_{3}$ may exacerbate pest problems and, moreover, changes in tropospheric chemistry can alter the key aspects of leaf chemistry which affect the feeding and demographic performance of insects, thereby modulate the risk of crop damage by insect herbivores (Ashmore and Bell, 1991).

Through changes in metabolic processes, ozone has an impact on the quality of host plants of the phytophagous insects which indirectly can influence both the phytophagous insects and their predators and parasites (Holton et al., 2003). Agrell et al. (2005) introduced a phytophagous forest pest insect (Malacosomadisstria) whose food preferences changed as a result of ozone concentration change. 
Holopainen et al.(1997), Peltonen et al. (2006) and Percy et al.(2002) give further examples on the phytotoxic effects of plant-mediated $\mathrm{O}_{3}$ on the behavior and functional activity of insects.

\section{Ozone in pest-predator relations}

Pinto et al. (2007, 2008) formulated their conjecture that, during an oxidative reaction, ozone degrades herbal fragrances induced from the host plant by the herbivores. Since herbal fragrances serve as an important signal for the natural enemies (predators or parasitoids) of herbivores, elevated ozone can weaken their orientation efficiency to find their prey or host (Butler et al, 2009; Gate et al., 1995; Holton et al., 2003; Dahlsten et al., 1997). Percy et al. (2002) detected significantly lower number of parasitoids under elevated ozone circumstances.

Though several publications consider the effect of tropospheric ozone concentration on plants or on the plant-insect communities, very few papers has its object on the relationship of ozone content of the air and insect activity. In an earlier study (Puskás et al., 2001), the authors detected the increase of the number of European Corn Borer (Ostrinia nubilalis Hbn.; Lepidoptra: Pyraustidae) caught when the ozone content in air was high. Puskás and Nowinszky (2010) established the same in case of the Scarce Bordered Straw (Helicoverpa armigera Hbn.) and other harmful insects (Nowinszky and Puskás, 2011). Valli and Callahan (1968) indicated an inverse relationship between $\mathrm{O}_{3}$ and insect activity, applying light traps.

Jones et al. (2004) have shown that elevated ozone concentration increase the susceptibility of the trees to bark beetles. Dahlstein et al. (1997) agree with Stark et al. (1968) and Grodzki et al., (2004) as they all have found that the number of Dendroctonus brevicornis and Dendroctonus ponderosae species increased while the number of their predators and parasitoids decreased on trees injured by ozone.

\section{Ozonone as disinfectant}

Extremely high concentration of ozone is harmful to insects. The study of Kells et al. (2001) evaluated the efficacy of ozone as a fumigant to disinfest stored maize. Treatment of 8.9 tonnes of maize with $50 \mathrm{ppm}$ ozone for 3 days resulted in 92-100\% mortality of adult Red Flour Beetle, Tribolium castaneum (Herbst), adult Maize Weevil, Sitophilus zeamais (Motsch.), and larval Indian Meal Moth, Plodia interpunctella (Hübner).

Biological effects of ozone have been investigated by Qassem (2006) as an alternative method for grain disinfestations. Ozone at concentration of $0.07 \mathrm{~g} / \mathrm{m}^{3}$ killed adults of Grain Weevil (Sitophilus granarius L.), Rice Weevil (Sitophilus oryzae L.) and Lesser Grain Borer (Rhyzopertha dominica Fabr.) after 5-15 hours of exposure. Adult death of Rice Flour Beetle (Tribolium confusum Duv.) and Saw-toothed Grain Beetle (Oryzaephilus surinamensis L.) was about 50\% after 15-20 hours of exposure. Total adult death of all insect species was made with $1.45 \mathrm{~g} / \mathrm{m}^{3}$ ozone concentration after one hour of exposure. According to Bonjour et al. (2011), ozone fumigation has potential for the control of some stored grain insect pests on wheat.

\section{Ozone effect experiments in laboratories}

Direct effects of ozone on insects can be investigated mainly in laboratories while observations can supply information on complex (both direct and indirect) interactions, 
though exploring the relationship need high level caution (Alstad et al., 1982; Freedman, 1994; Butler et al., 2009).

Beard (1965) and Levy et al. (1972) executed long-term experiments on Musca domestica and Drosophila and Stomoxys calcitrans. They observed that ozone stimulated the ovipositional activity of female flies and the number of laid eggs was five times higher at elevated ozone concentration than at control circumstances.

Mondor et al. (2004) observed that in case ozone concentration was high, the intensity of escape reaction of Chaitophorus stevensis species has changed, the dispersity of the community increased sinificantly.

\section{Observed ozone effect on ecosystems}

Human-induced climate changes threaten the health of forest ecosystems. In particular, carbon dioxide $\left(\mathrm{CO}_{2}\right)$ and tropospheric ozone $\left(\mathrm{O}_{3}\right)$ will likely have significant but opposing impacts on forests and their associated insect communities. Hillstrom and Lindroth (2008) claim that, compared with other animal groups, insect communities are expected to be especially sensitive to changes in global climate. According to their observations between 2000 and 2003, elevated $\mathrm{CO}_{2}$, and $\mathrm{O}_{3}$, or both significantly affected insect community compositions in all years.

Since insects play key roles in forest ecosystems, changes in insect abundance, diversity or community composition have the potential to alter forest ecosystems. Regular monitoring and research on their response to global change is critically important to forest management and conservation.

\section{Ozone and $U V$ radiation}

In previous studies of the authors (Puskás et al., 2001), it was proved that the ozone content of the air influences the strength of UV-B radiation which in its turn, bears an impact on the effectiveness of collecting insects by light-trap. Therefore, it seemed reasonable to find a direct empirical connection between the ozone content of the air and the number of trapped insects.

\section{Materials and methods}

\section{The trapped species}

\section{European Vine Moth (Lobesia botrana Den. et Schiff.)}

European Vine Moth is native to Southern Italy. It can be found throughout Europe in the Mediterranean, southern Russia, the Middle East, Near East, and northern and western Africa and Asia north of the Himalayas to Japan. Grape (Vitis vinifera) is its preferred hosts, but it has also been reported on several fruits (e.g. olive, blackberry, cherry, nectarine, persimmons and pomegranate) and a number of wild hosts (Briere and Pracros, 1998).

European grapevine moth has two generations in northern Europe, three generations in southern Europe including Hungary (Milonas et al., 2001). In May and June, firstgeneration larvae web and feed on the flower clusters. Second-generation larvae (JulyAugust) feed on green berries. Third-generation larvae (August-September) cause the greatest damage by feeding inside berries. Additionally, feeding damage to berries after veraison exposes them to infection by Botrytis and other secondary fungi and pests 
(Sáenz-de-Cabezón et al., 2005). European Vine Moth appears in all the wine-growing regions of Hungary, in very different frequency.

\section{Spotted Tentiform Leafminer (Phyllonorycter blancardella Fabr.)}

Tentiform leafminer was introduced from Europe in the 1930s. Populations in commercial orchards increased dramatically in the 1970s and 80s as the insect became resistant to organophosphate insecticides. The species is now distributed throughout Europe, the Baltic States, Byelorussia, Ukraine and Moldova as well as the European part of Russia, Transcaucasia, Urals, Asia Minor, Iran, Mongolia, and Northern America (Pfeiffer et al., 1995).

There are usually 2-5, mostly three generations of tentiform leafminer a year in Hungary. The insect overwinters as a pupa in leaves on the orchard floor. Adult moths begin to emerge when apple buds begin to break in late April and continue to emerge throughout May. The spotted tentiform leafminer infests apple. The larvae mine between layers of apple leaves, reducing photosynthetic area. Heavy infestations of leafminer affect fruit sizing, reduce vegetative growth and/or cause premature fruit drop.

\section{Setaceous Hebrew Character (Xestia c-nigrum L.)}

It is found in the Palearctic ecozone woodland. It is a common species throughout Europe, Britain and also can be found in North America, from coast to coast across Canada and the northern United States to western Alaska.

In the southern half of its range, including Hungary, there are two broods, flying in small numbers in May and June, but far more commonly in August and September. In the north there is just one generation, flying in July and August (Thompson and Nelson, 2003).

It is polyphagous, the larvae feed on a variety of herbaceous (agricultural and horticultural) plants, but especially nettle (Urtica). include plants.

\section{Latticed Heath (Chiasmia clathrata L.).}

This species can be found throughout Europe from the Iberian Peninsula north to Scandinavia and east to Greece and Turkey and extends to eastern Siberia, China and Japan, North Africa, Central Asia, Siberia and the Far East.

The larvae feed on lucerne (Medicago sativa) and clover (Trifolium), however, it occurs in a range of open habitats, including moorland, grassland and waste ground.

There are usually two generations, especially in the south, flying in May and June, and August and September, and the species flies by day as well as at night.

\section{April Beetle (Rhizotrogus aequinoctialis Herbst.).}

It is distributed in Europe and in the Northern Mediterranean basin. It has a threeyear development cycle. The adult does not feed; the larvae eat humus and different kinds of root. The larvae feed especially on herbaceous plants in moorland, grassland and waste ground but they can be found in orchards, vineyards and forest nurseries, too. Swarming is usually between end of March and beginning of June, mainly from noon to night (Janik et al., 2008).

\section{Ecnomus tenellus Rambur}

This caddishfly is one of most abundant insect which can be found in Hungary highland as well as in various natural and artificial lakes, backwaters, salt ponds, ditches 
and slow water rivers. Their presence often indicates degraded, low oxygen content water and plays an important role in aquatic ecosystems as fish food. The larvae have predatory lifestyle. The adults have cyclic pattern of flight activity from May till September with several peaks and without diapauses or parapauses (Nógrádi and Uherkovich, 2002; Kiss et al., 2006; Graf et al.,2008).

\section{The examined sites and years}

The data of investigated species and years, the number of observation stations and average value of ozone concentration in the examined period can be found in Table 1.

We worked with the ozone data measured at 23 o'clock (UT). Regardless of the number of insects caught, it was recorded whether or not the traps were successful in catching at a night (successful observation). The number of successful observations exceeds the number of the nights because not a single light-trap worked at a night.

Table 1. Observed data of the examined species caught

\begin{tabular}{|c|c|c|c|c|c|}
\hline \multicolumn{6}{|c|}{ Pheromone trap catch } \\
\hline & & & \multicolumn{3}{|c|}{ Number of } \\
\hline Species & $\begin{array}{l}\text { Mean } \\
\text { Ozone } \\
\text { content } \\
\left(\mu \mathrm{g} / \mathrm{m}^{3}\right)\end{array}$ & Years & $\begin{array}{l}\text { Trap } \\
\text { sites }\end{array}$ & $\begin{array}{l}\text { Individuals } \\
\text { caught }\end{array}$ & $\begin{array}{c}\text { Successful } \\
\text { Observations }\end{array}$ \\
\hline $\begin{array}{l}\text { European Vine Moth } \\
\text { Lobesia botrana Den. et Schiff. } \\
\text { Lepidoptera Tortricidae }\end{array}$ & 48.9 & $\begin{array}{l}2004- \\
2011\end{array}$ & 1 & 8053 & 1961 \\
\hline $\begin{array}{l}\text { Spotted Tentiform Leafminer } \\
\text { Phyllonoricter blancardella Fabr. } \\
\text { Lepidoptera: Lithocolletidae }\end{array}$ & 47.9 & $\begin{array}{l}2004- \\
2011\end{array}$ & 1 & 58248 & 2387 \\
\hline \multicolumn{6}{|c|}{ Light-trap catch } \\
\hline & & & \multicolumn{3}{|c|}{ Number of } \\
\hline Species & $\begin{array}{c}\text { Mean } \\
\text { Ozone } \\
\text { content } \\
\left(\mu \mathrm{g} / \mathrm{m}^{3}\right)\end{array}$ & Years & $\begin{array}{l}\text { Trap } \\
\text { sites }\end{array}$ & $\begin{array}{l}\text { Individuals } \\
\text { caught }\end{array}$ & $\begin{array}{c}\text { Successful } \\
\text { Observations }\end{array}$ \\
\hline \multirow[t]{2}{*}{$\begin{array}{l}\text { European Vine Moth } \\
\text { Lobesia botrana Den. et Schiff. } \\
\text { Lepidoptera Tortricidae }\end{array}$} & 52.5 & $\begin{array}{l}2004 \\
2005 \\
2007 \\
2008\end{array}$ & 1 & 3820 & 342 \\
\hline & 24.6 & 2006 & 1 & 1628 & 120 \\
\hline \multirow{2}{*}{$\begin{array}{l}\text { Setaceous Hebrew Character } \\
\text { Xestia c-nigrum L. } \\
\text { Lepidoptera: Noctuidae }\end{array}$} & 64.3 & $\begin{array}{l}2004- \\
2008 \\
\end{array}$ & 10 & 10729 & 921 \\
\hline & 47.7 & $\begin{array}{l}2009- \\
2011\end{array}$ & 10 & 3913 & 694 \\
\hline \multirow{2}{*}{$\begin{array}{l}\text { Latticed Heath } \\
\text { Chiasmia clathrata } L \text {. } \\
\text { Lepidoptera: Geometridae }\end{array}$} & 67.1 & $\begin{array}{l}2007, \\
2008, \\
2011\end{array}$ & 10 & 3564 & 851 \\
\hline & 31.6 & $\begin{array}{l}2005- \\
2006\end{array}$ & 21 & 6789 & 1078 \\
\hline $\begin{array}{l}\text { April Beetle } \\
\text { Rhizotrogus aequinoctialis Herbst } \\
\text { Coleoptera: Melolonthidae }\end{array}$ & 79.3 & $\begin{array}{l}2004- \\
2007 \\
2009- \\
2011\end{array}$ & 2 & 1924 & 272 \\
\hline $\begin{array}{l}\text { Ecnomus tenellus Rambur } \\
\text { Trichoptera: Ecnomidae }\end{array}$ & 25.6 & $\begin{array}{l}2001- \\
2005\end{array}$ & 5 & 21717 & 848 \\
\hline
\end{tabular}


It is clear that the sizes of the populations are very different at different sites and time intervals. Therefore we calculated the dimension-free relative catch (RC) data for each observation site and day. The RC is the quotient of the number of individuals caught by a trap during a sampling time unit (1 night) and the average number of individuals of the same generation caught in the same time unit calculated over the whole experimental area (Nowinszky, 2003).

The relationship of the ozone content of the air $\left(\mu \mathrm{g} / \mathrm{m}^{3}\right)$ and the relative catch values was investigated.

\section{The general model}

We defined a general model of the form:

$$
\begin{aligned}
& Y=\chi\left[X<p_{0}\right] *\left[p_{1}+\left(p_{2}-p_{1}\right) /\left(1+\exp \left(-p_{3} *\left(X-p_{4}\right)\right)\right)\right]+ \\
& \chi\left[X \geq p_{0}\right] *\left[p_{2}+\left(p_{5}-p_{2}\right) /\left(1+\exp \left(-p_{6} *\left(X-p_{7}\right)\right)\right)\right]+\varepsilon
\end{aligned}
$$

where $Y$ denotes the relative catch (RC) while $X$ is for the ozone content of the air $\left[\mu \mathrm{g} / \mathrm{m}^{3}\right]$ and $\varepsilon$ is a normally distributed error term with expected value of zero;

$\chi\left[X<p_{0}\right], \chi\left[X \geq p_{0}\right]$ are characteristics functions which take 1 if the condition given in brackets $\left[X<p_{0}\right]$ or $\left[X \geq p_{0}\right]$ holds and zero if it is false;

$p_{1}$ is the parameter the fitting curve approaches as $X \rightarrow-\infty$;

$p_{2}$ is the parameter the fitting curve approaches as $X \rightarrow p_{0}$;

$p_{5}$ is the parameter the fitting curve approaches as $X \rightarrow+\infty$;

$p_{3}$ and $p_{6}$ are velocity factors of the exponential terms;

$p_{4}$ and $p_{7}$ are parameters which represent the inflexion points of the models.

The general model has the shape of Fig. 1. The curve can be split into four sections. The different sections can be expressed in different forms of exponential or saturation models. Section 1 and 2 or Section 3 and 4 together can be called as logistic (S-shape) models. Thus Section 1,2, 3 and 4 together can be regarded as a "bi-logistic model".

We have chosen different special nonlinear regression models to fit the distinct type of data of different sites and time scales. All the models can be originated as a part of the general model of (Eq.1). We applied saturation models (Models 1, 4, 5, 8 and 9), exponential model of two different forms (Model 3 and 10), transformed saturation model (Model 11), logistic model (Model 2) and bi-logistic models (Models 6 and 7) in the forms given in the Tables 1-6. In the models $Y$ denotes the relative catch (RC) while $X$ is for the ozone content of the air $\left[\mu \mathrm{g} / \mathrm{m}^{3}\right]$ and $\varepsilon$ is a normally distributed error term with expected value of zero. Normality was tested by Shapiro-Wilk test ( $>>0.05)$. 


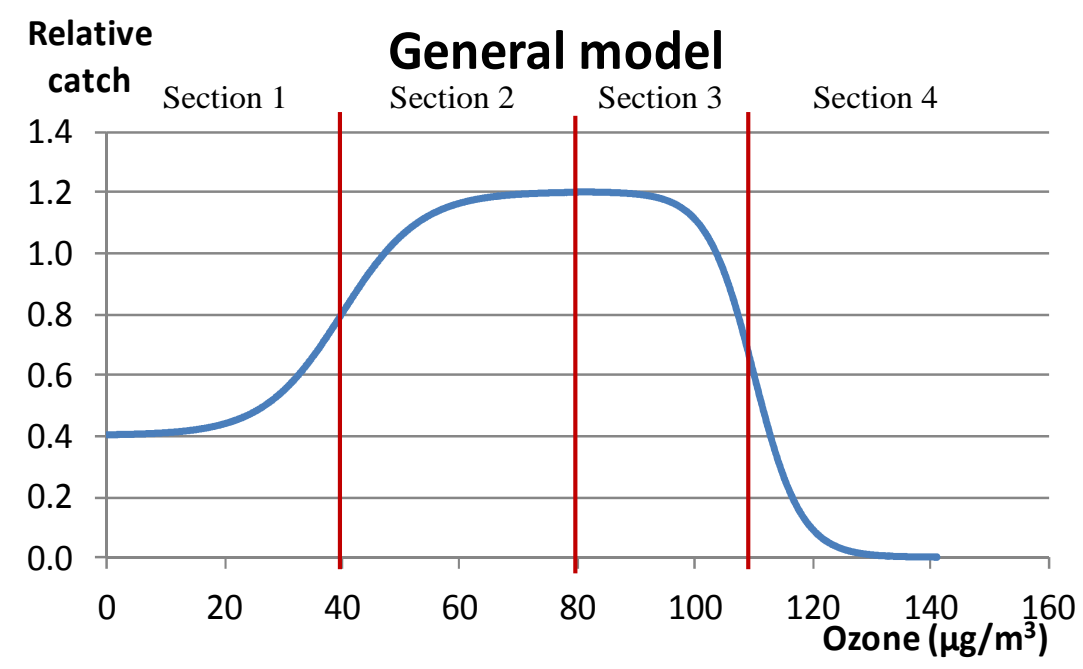

Figure 1. General model of relative catch depending on the ozone content of the air $\left[\mu \mathrm{g} / \mathrm{m}^{3}\right]$ expressed in form (Eq. 1) with parameters $p_{0}=80 ; p_{1}=0.4 ; p_{2}=1.2 ; p_{3}=0.15$;

$$
p_{4}=40 ; p_{5}=0 ; p_{6}=0.25 \text { and } p_{7}=110 \text {. }
$$

The parameter estimations were calculated together with their $t$-values and significance levels. The models were tested by the $F$-value and its significance level. Finally the explained variance $\left(R^{2}\right)$ was evaluated.

\section{Results}

Model 1, Model 4, Model 5, Model 8 and Model 9 are saturation models where $p_{1}$ is the parameter the fitting curve takes at point $X=0$;

$p_{2}$ is the parameter which represents the change of the fitting curve values on the whole range of ozone content in the experiment;

$p_{3}$ is a velocity factor of the exponential term.

In Model 2 (logistic model)

$p_{1}$ is the parameter the fitting curve approaches as $X \rightarrow-\infty$;

$p_{2}$ is the parameter the fitting curve approaches as $X \rightarrow+\infty$;

$p_{3}$ is a velocity factor of the exponential term;

$p_{4}$ is the parameter which represents the inflexion point of the model.

In Model 3 (exponential model) $p_{1}$ is a coefficient of the exponential term; $p_{2}$ is a velocity factor of the exponential term.

In Models 6 and 7 we applied the general model in form of Eq(1). 
Table 2. Nonlinear regression models of the relative catch of Lobesia botrana Den. et Schiff.(depending on the ozone content of the air $\left[\mu \mathrm{g} / \mathrm{m}^{3}\right]$ at different sites and time intervals with their parameter estimates, together with the regression diagnostics( $F$ values of the models, $t$ values of the parameters and the explained variance $R^{2}$ )

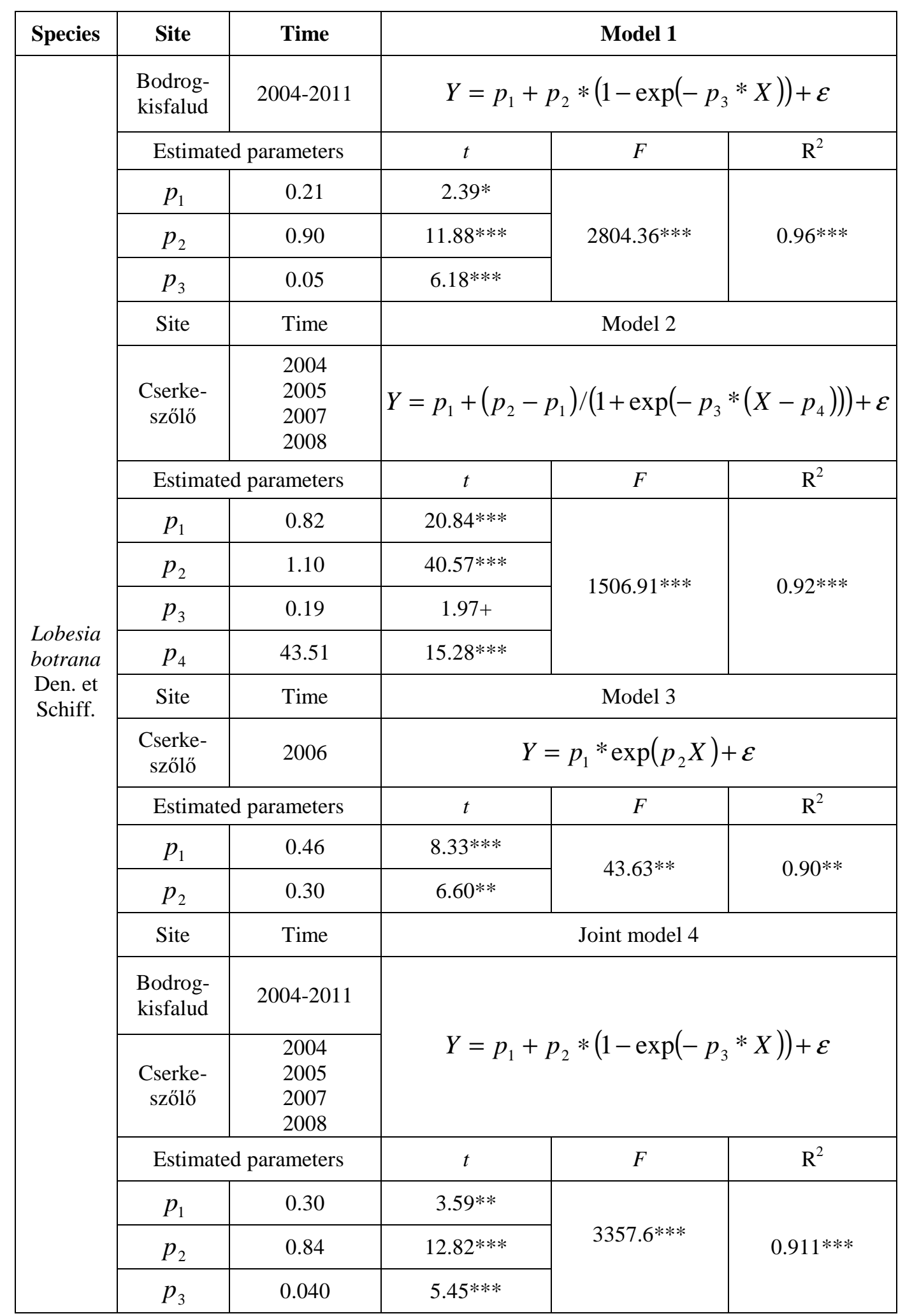

+ significant at $\mathrm{p}<0.1 ; *$ significant at $\mathrm{p}<0.05 ; * *$ significant at $\mathrm{p}<0.01 ; * * *$ significant at $\mathrm{p}<0.001$ 


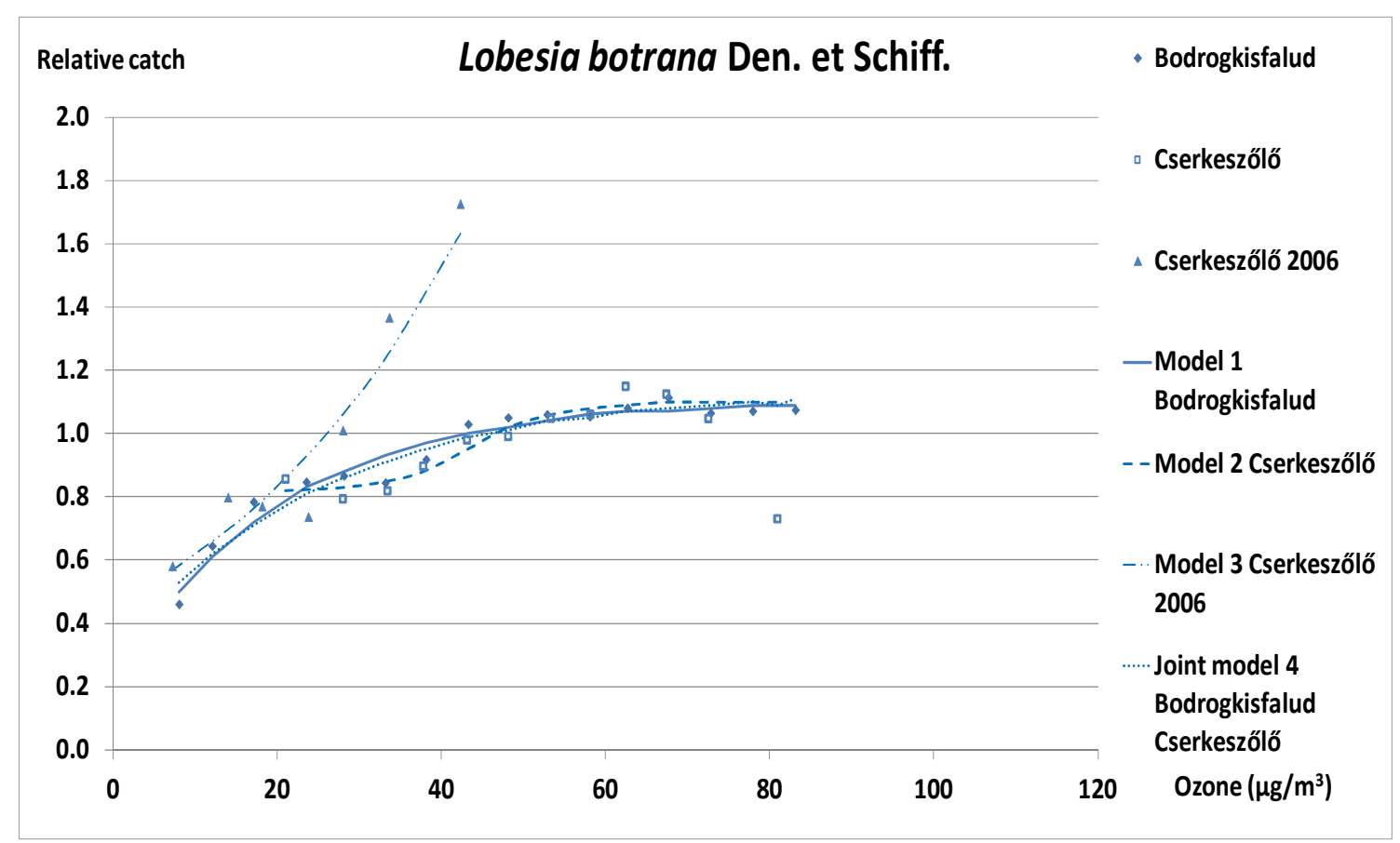

Figure 2. Observed relative catch values and the fitted curves of nonlinear regression models relative to Lobesia botrana Den. et Schiff. depending on the ozone content of the air $\left[\mu \mathrm{g} / \mathrm{m}^{3}\right]$ at different sites and time intervals

Relative catch data of Lobesia botrana Den. et Schiff., Bodrogkisfalud showed saturation growth (Model 1, Fig. 2, Table 2). In 2006 we measured significantly lower ozone content in the air in Cserkeszölö and detected different character of relative catch responses of Lobesia botrana Den. et Schiff. Therefore, we fitted a quickly growing exponential model to the relative catch data of 2006 (Model 3, Fig. 2, Table 2) and a slowly growing logistic model to the data in other years in Cserkeszölö (Model 2, Fig. 2, Table 2). Nevertheless, considering the growing speed, Model 1 and Model 2 can be regarded similar, thus we fitted a joint (saturation) model (Model 4) which can substitute Model 1 and 2, i.e. it can represent the data a Bodrogkisfalud and also Cserkeszölö but the year 2006 (Fig. 1, Table 2).

Table 3. Nonlinear regression models of the relative catch of Lobesia botrana Den. et Schiff. depending on the ozone content of the air $\left[\mu \mathrm{g} / \mathrm{m}^{3}\right]$ at different sites and time intervals with their parameter estimates, together with the regression diagnostics( $F$ values of the models, $t$ values of the parameters and the explained variance $R^{2}$ )

\begin{tabular}{|c|c|c|c|c|c|}
\hline Species & Site & Time & \multicolumn{3}{|c|}{ Model 5} \\
\hline \multirow{5}{*}{$\begin{array}{c}\text { Phyllonoricte } \\
\text { blancardella } \\
\text { Fabr. }\end{array}$} & $\begin{array}{l}\text { Bodrog- } \\
\text { kisfalud }\end{array}$ & 2004-2011 & \multicolumn{3}{|c|}{$Y=p_{1}+p_{2} *\left(1-\exp \left(-p_{3} * X\right)\right)+\varepsilon$} \\
\hline & Estimated & arameters & $t$ & $F$ & $\mathrm{R}^{2}$ \\
\hline & $p_{1}$ & 0.20 & $2.41^{*}$ & \multirow{3}{*}{$1979.64 * * *$} & \multirow{3}{*}{$0.96 * * *$} \\
\hline & $p_{2}$ & 1.03 & $16.85 * * *$ & & \\
\hline & $p_{3}$ & 0.03 & $5.19 * * *$ & & \\
\hline
\end{tabular}

\footnotetext{
$*$ significant at $\mathrm{p}<0.05 ; * *$ significant at $\mathrm{p}<0.01 ; * * *$ significant at $\mathrm{p}<0.001$
} 


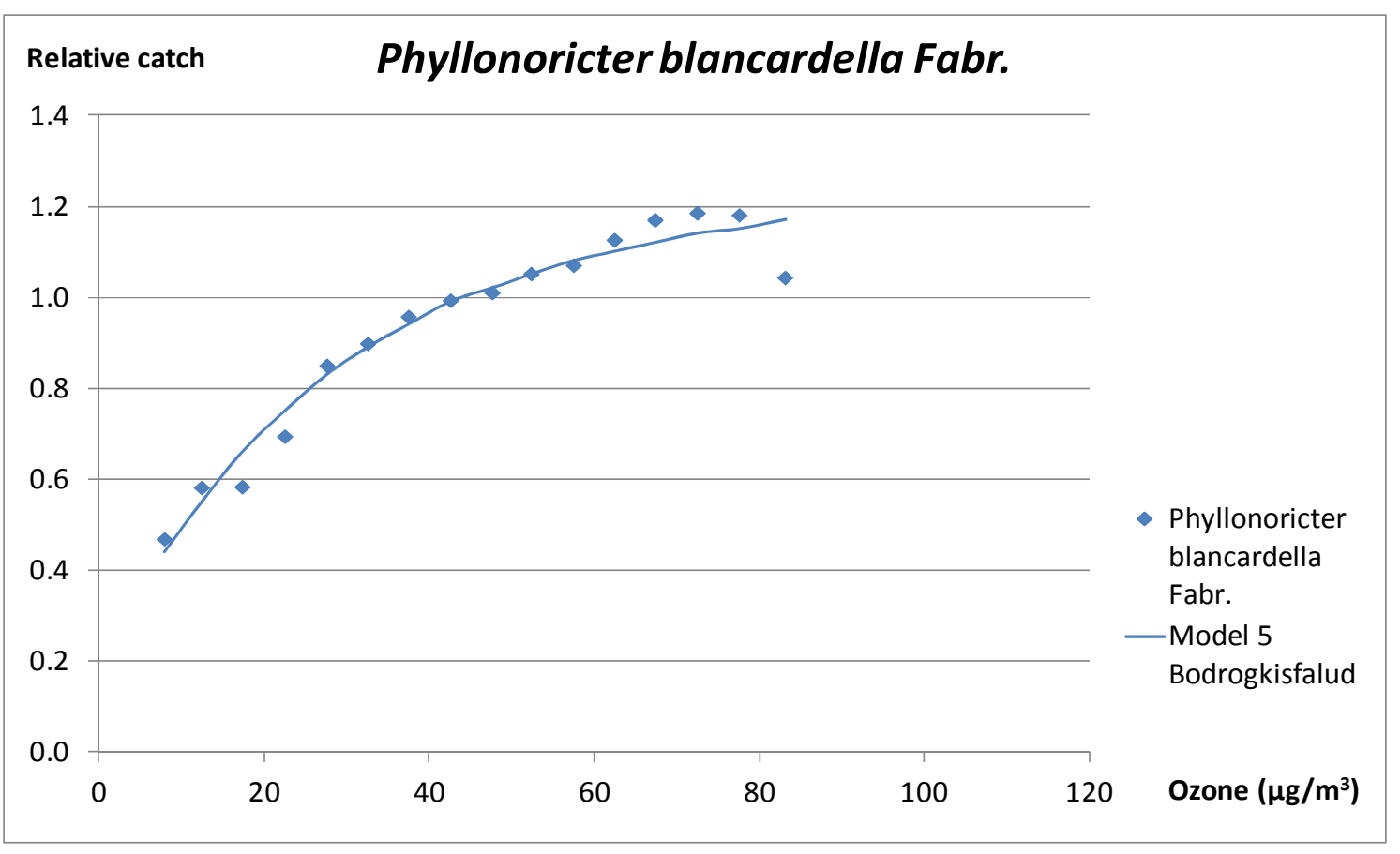

Figure 3. Observed relative catch values and the fitted curve of nonlinear regression model relative to Phyllonoricter blancardella Fabr. depending on the ozone content of the air $\left[\mu \mathrm{g} / \mathrm{m}^{3}\right]$ at Bodrogkisfalud (2004-2011)

In case of Phyllonoricter blancardella Fabr., we fitted a slowly growing saturation model (Fig. 3) that is very similar to the Model 1 and joint Model 4 of Lobesia botrana Den. et Schiff. which indicates a presumably similar response strategy of the two species when the ozone content of the air is below $90 \mu \mathrm{g} / \mathrm{m}^{3}$.

According to the calculated determination coefficients, all the Models 1-5 explain more than $90 \%$ of the variance of the observed data and have highly significant $F$ values as well. By the significant (in most cases highly significant) $t$ values all the parameter estimates can be judged as reliable (Table 2 and Table 3).

Xestia c-nigrum L. was trapped at 10 sites between 2004 and 2011. In the years 2009-2012, during the observation period, lower mean ozone content of the air was measured than in years 2004-2008 and the relative catch data followed distinguishably different curves (Fig. 4). Therefore, we split the data into two (2004-2008 and 20092011) and fitted two different models with the same form (Eq.1) of the general model (Model 6 and Model 7, Table 4, Fig. 4).

After an increase of relative catch with increasing ozone content of air, we noticed a definite fall of the number of relative catches when the ozone content exceeded a critical value, and this was detectable in both time scales but at different critical values of ozone content (i.e. $80 \mu \mathrm{g} / \mathrm{m}^{3}$ in earlier years with higher ozone content and $44 \mu \mathrm{g} / \mathrm{m}^{3}$ in the later years with lower mean ozone content of the air). 
Table 4. Nonlinear regression models of the relative catch of Xestia c-nigrum L. depending on the ozone content of the air $\left[\mu \mathrm{g} / \mathrm{m}^{3}\right]$ at different sites and time intervals with their parameter estimates, together with the regression diagnostics( $F$ values of the models, $t$ values of the parameters and the explained variance $R^{2}$ )

\begin{tabular}{|c|c|c|c|c|c|}
\hline Species & $\begin{array}{c}\text { Number of } \\
\text { observation } \\
\text { sites }\end{array}$ & $\begin{array}{l}\text { Time with } \\
\text { higher } \\
\text { ozone } \\
\text { content }\end{array}$ & \multicolumn{3}{|c|}{ Model 6 at higher mean ozone content } \\
\hline \multirow{19}{*}{$\begin{array}{l}\text { Xestia } \\
c- \\
\text { nigrum } \\
\text { L. }\end{array}$} & 10 & 2004-2008 & \multicolumn{3}{|c|}{$\begin{array}{l}Y=\chi[X<80] *\left[p_{1}+\left(p_{2}-p_{1}\right) /\left(1+\exp \left(-p_{3} *\left(X-p_{4}\right)\right)\right)\right]+ \\
\chi[X \geq 80] *\left[p_{2}+\left(p_{5}-p_{2}\right) /\left(1+\exp \left(-p_{6} *\left(X-p_{7}\right)\right)\right)\right]+\varepsilon\end{array}$} \\
\hline & \multicolumn{2}{|c|}{ Estimated parameters } & $t$ & $F$ & $\mathrm{R}^{2}$ \\
\hline & $p_{1}$ & 0.46 & $6.07 * * *$ & \multirow{7}{*}{$769.49 * * *$} & \multirow{7}{*}{$0.96^{* * *}$} \\
\hline & $p_{2}$ & 1.16 & $37.50 * * *$ & & \\
\hline & $p_{3}$ & 0.16 & $3.46^{* *}$ & & \\
\hline & $p_{4}$ & 40.36 & $19.32 * * *$ & & \\
\hline & $p_{5}$ & 0.73 & $7.30 * * *$ & & \\
\hline & $p_{6}$ & 0.01 & $0.2 \mathrm{~ns}$ & & \\
\hline & $p_{7}$ & 80 & $0.11 \mathrm{~ns}$ & & \\
\hline & $\begin{array}{l}\text { Number of } \\
\text { observation } \\
\text { sites }\end{array}$ & $\begin{array}{l}\text { Time with } \\
\text { lower } \\
\text { ozone } \\
\text { content }\end{array}$ & \multicolumn{3}{|c|}{ Model 7 at lower mean ozone content } \\
\hline & 10 & 2009-2011 & \multicolumn{3}{|c|}{$\begin{array}{l}Y=\chi[X<44] *\left[p_{1}+\left(p_{2}-p_{1}\right) /\left(1+\exp \left(-p_{3} *\left(X-p_{4}\right)\right)\right)\right]+ \\
\chi[X \geq 44] *\left[p_{2}+\left(p_{5}-p_{2}\right) /\left(1+\exp \left(-p_{6} *\left(X-p_{7}\right)\right)\right)\right]+\varepsilon\end{array}$} \\
\hline & \multicolumn{2}{|c|}{ Estimated parameters } & $t$ & $F$ & $\mathrm{R}^{2}$ \\
\hline & $p_{1}$ & 0.62 & $15.08 * * *$ & \multirow{7}{*}{$1383.02 * * *$} & \multirow{7}{*}{$0.99 * * *$} \\
\hline & $p_{2}$ & 1.25 & $19.06^{* * *}$ & & \\
\hline & $p_{3}$ & 0.22 & $3.57 * *$ & & \\
\hline & $p_{4}$ & 29.32 & $21.49 * * *$ & & \\
\hline & $p_{5}$ & 0.20 & $0.92 \mathrm{~ns}$ & & \\
\hline & $p_{6}$ & 0.09 & $3.03 *$ & & \\
\hline & $p_{7}$ & 72.66 & $15.92 * * *$ & & \\
\hline
\end{tabular}

+significant at $\mathrm{p}<0.1 ; *$ significant at $\mathrm{p}<0.05$; ** significant at $\mathrm{p}<0.01$; *** significant at $\mathrm{p}<0.00 ;$ ns not significant 


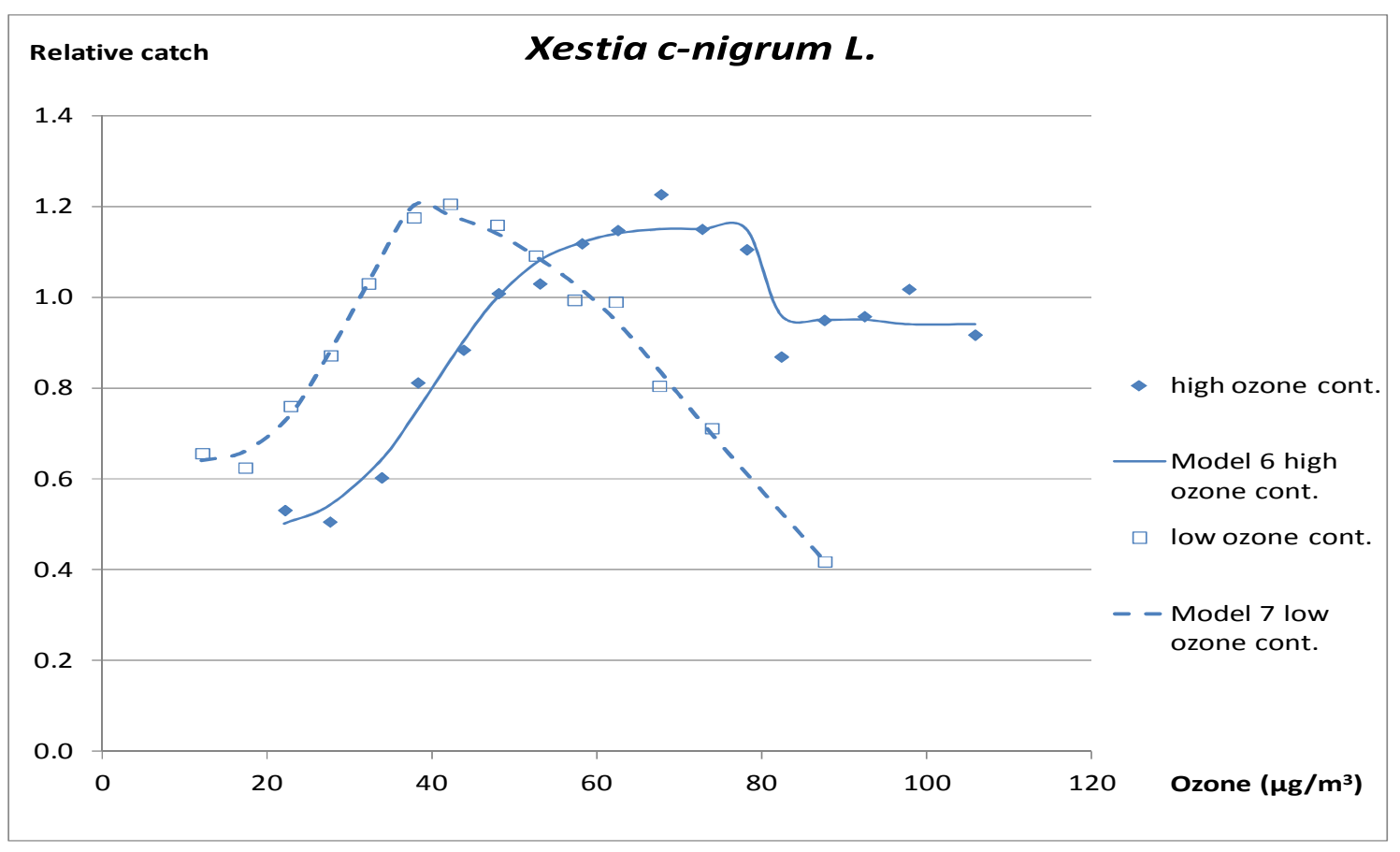

Figure 4. Observed relative catch values and the fitted curves of nonlinear regression models relative to Xestia c-nigrum. L. depending on the ozone content of the air $\left[\mu \mathrm{g} / \mathrm{m}^{3}\right], 2004-2011$

According to the calculated determination coefficients, both Models 6 and 7 explain $96 \%$ of the variance of the observed data and have highly significant $F$ values as well (Table 4). Most of the estimated parameters have significant $t$ values except $p_{6}$ and $p_{7}$ of Model 6 (i.e. velocity term and inflexion point of Section 3 with 4 of General model, Fig. 1) and $p_{5}$ of Model 7 (the limit of the model as $X \rightarrow+\infty$ ). In case of Model 6 the second part of the model (Section 3 and 4 of the General model) does not fit very well, indeed. For Model 7 the reason of insignificant parameter estimation is that the there is no observation in the range of ozone content of the air which corresponds to Section 4 of the General model (Fig. 1, Fig. 4).

Note that also in case of Lobesia botrana Den. et Schiff and Phyllonoricter blancardella Fabr. we observed significantly lower relative catch when the ozone content exceeded $80 \mu \mathrm{g} / \mathrm{m}^{3}$, however, we should not go far with consequences as there was not enough number of such events available to model.

Chiasmia clathrata L. was trapped altogether at 21 sites between 2005 and 2011 but in years 2009 and 2010. In the years 2005-2006, during the observation period, lower mean ozone content of the air was measured than in years 2007, 2008 and 2011, and, similarly to the case of Xestia c-nigrum L., the relative catch data followed distinguishably different curves (Fig. 5). Therefore, again we split the data into two (2004-2005 and later years) and fitted two different models with the same form (Model 8 and Model 9, Table 5, Fig. 5). Relative catch of Chiasmia clathrata L. in both time intervals followed saturation model as the ones of Lobesia botrana Den. et Schiff. and Phyllonoricter blancardella Fabr. The most important difference is that in case we detected high ozone content of the air (i.e. above $80 \mu \mathrm{g} / \mathrm{m}^{3}$ ), instead of a fall we observed a slight increase of relative catch values (Fig. 5). 
Table 5. Nonlinear regression models of the relative catch of Chiasmia clathrata $L$. depending on the ozone content of the air $\left[\mu \mathrm{g} / \mathrm{m}^{3}\right](2005-2011)$ with their parameter estimates, together with the regression diagnostics $(F$ values of the models, $t$ values of the parameters and the explained variance $R^{2}$ )

\begin{tabular}{|c|c|c|c|c|c|}
\hline Species & \begin{tabular}{|} 
Number of \\
observation \\
sites
\end{tabular} & $\begin{array}{c}\text { Time with } \\
\text { higher } \\
\text { ozone } \\
\text { content }\end{array}$ & \multicolumn{3}{|c|}{ Model 8 at higher mean ozone content } \\
\hline \multirow{11}{*}{$\begin{array}{c}\text { Chiasmia } \\
\text { clathrata } \\
\text { L. }\end{array}$} & 10 & $\begin{array}{c}2007,2008, \\
2011\end{array}$ & \multicolumn{3}{|c|}{$Y=p_{1}+p_{2} *\left(1-\exp \left(-p_{3} * X\right)\right)+\varepsilon$} \\
\hline & Estimated & parameters & $t$ & $F$ & $\mathrm{R}^{2}$ \\
\hline & $p_{1}$ & 0.48 & $6.18^{* * * *}$ & \multirow{3}{*}{$1670.73 * * *$} & \multirow{3}{*}{$0.89 * * *$} \\
\hline & $p_{2}$ & 0.64 & $9.50 * * *$ & & \\
\hline & $p_{3}$ & 0.04 & $3.81 * *$ & & \\
\hline & $\begin{array}{c}\text { Number of } \\
\text { observation } \\
\text { sites }\end{array}$ & $\begin{array}{l}\text { Time with } \\
\text { lower ozone } \\
\text { content }\end{array}$ & \multicolumn{3}{|c|}{ Model 9 at lower mean ozone content } \\
\hline & 21 & 2005,2006 & \multicolumn{3}{|c|}{$Y=p_{1}+p_{2} *\left(1-\exp \left(-p_{3} * X\right)\right)+\varepsilon$} \\
\hline & \multicolumn{2}{|c|}{ Estimated parameters } & $t$ & $F$ & $\mathrm{R}^{2}$ \\
\hline & $p_{1}$ & 0.45 & $3.53 * *$ & \multirow{3}{*}{$870.03 * * *$} & \multirow{3}{*}{$0.85^{* * *}$} \\
\hline & $p_{2}$ & 0.71 & $6.40 * * *$ & & \\
\hline & $p_{3}$ & 0.60 & $2.92 *$ & & \\
\hline
\end{tabular}

* significant at $\mathrm{p}<0.05 ; * *$ significant at $\mathrm{p}<0.01 ; * * *$ significant at $\mathrm{p}<0.001$

According to the calculated determination coefficients, both Models 8 and 9 explain more than $85 \%$ of the variance of the observed data and have highly significant $F$ values as well (Table 5). By the significant (in most cases highly significant) $t$ values all the parameter estimates can be judged as reliable. 


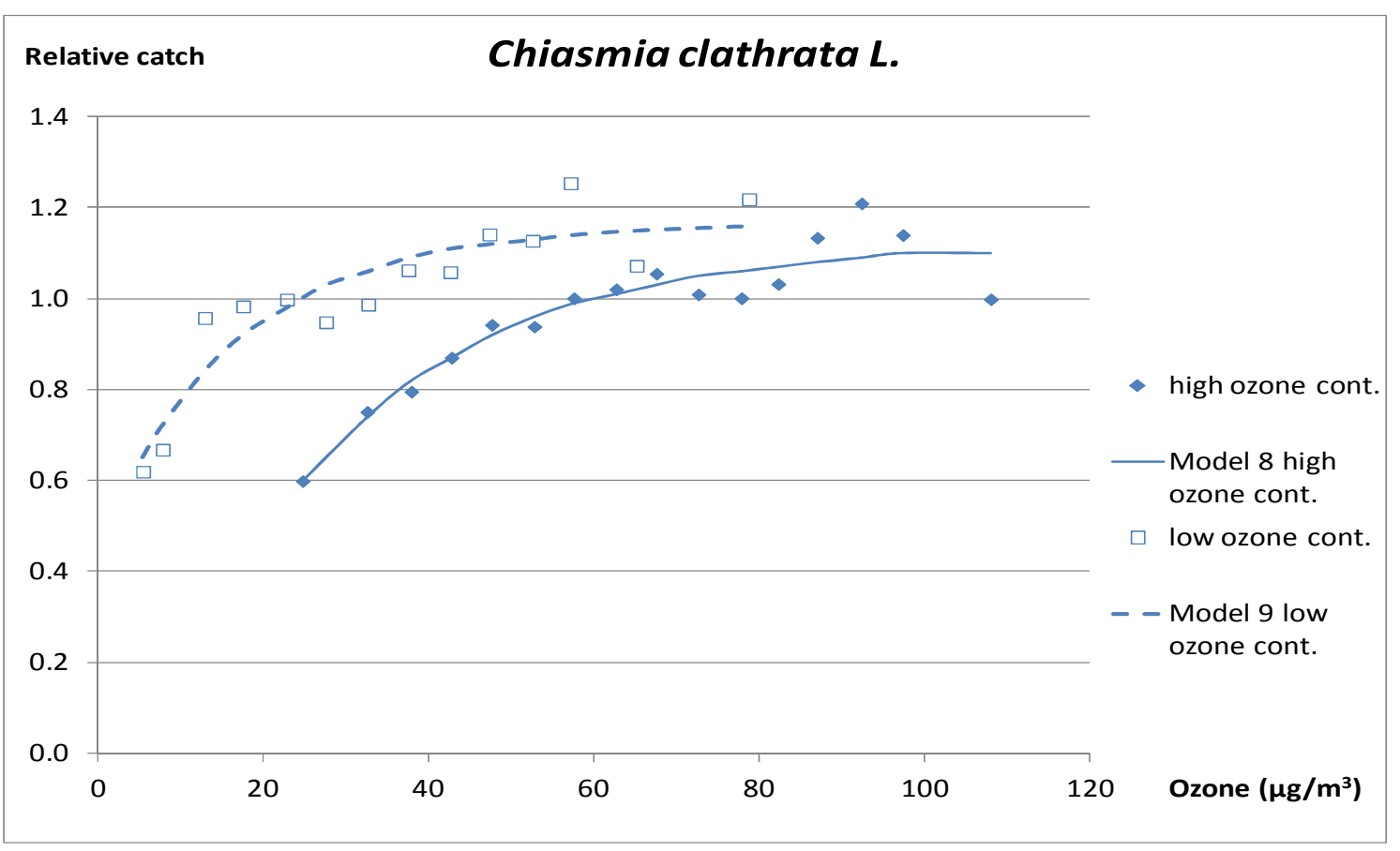

Figure 5. Observed relative catch values and the fitted curves of nonlinear regression models relative to Chiasmia clathrata L. depending on the ozone content of the air $\left[\mu \mathrm{g} / \mathrm{m}^{3}(2005-2011)\right.$

Rhizotrogus aequinoctialis Herbst was trapped altogether at 21 sites between 2005 and 2011 but in 2008. In contrary to the cases of Lobesia botrana Den. et Schiff., Phyllonoricter blancardella Fabr. and Xestia c-nigrum L., relative catch data of Rhizotrogus aequinoctialis Herbst show a definite increase if the ozone content of the air exceeds $80 \mu \mathrm{g} / \mathrm{m}^{3}$ (Fig. 6). In its model (Model 10) the exponential term is multiplied by a linear term the coefficients of which are $p_{1}$ (slope) and $p_{2}$ (intersection) while $p_{3}$ is a velocity factor of the exponential term (Table 6).

Table 6. Nonlinear regression models of the relative catch of Rhizotrogus aequinoctialis Herbst depending on the ozone content of the air $\left[\mu \mathrm{g} / \mathrm{m}^{3}\right](2004-2011)$ with their parameter estimates, together with the regression diagnostics( $F$ values of the models, $t$ values of the parameters and the explained variance $R^{2}$ )

\begin{tabular}{|c|c|c|c|c|c|}
\hline Species & $\begin{array}{c}\text { Number of } \\
\text { observation } \\
\text { sites }\end{array}$ & Time & \multicolumn{3}{|c|}{ Model 10} \\
\hline \multirow{5}{*}{$\begin{array}{c}\text { Rhizotrogus } \\
\text { aequinoctialis } \\
\text { Herbst }\end{array}$} & 2 & $\begin{array}{l}2004-2007 \\
2009-2011\end{array}$ & \multicolumn{3}{|c|}{$Y=\left(p_{1} X+p_{2}\right) *\left(\exp \left(-p_{3} * X\right)\right)+\varepsilon$} \\
\hline & \multicolumn{2}{|c|}{ Estimated parameters } & $t$ & $F$ & $\mathrm{R}^{2}$ \\
\hline & $p_{1}$ & 0.17 & $11.13^{* * * *}$ & \multirow{3}{*}{$44.56 * * *$} & \multirow{3}{*}{$0.94 * * *$} \\
\hline & $p_{2}$ & -0.10 & $-3.58 * *$ & & \\
\hline & $p_{3}$ & -0.04 & $-7.31 * * *$ & & \\
\hline
\end{tabular}

$*$ significant at $\mathrm{p}<0.05 ; * *$ significant at $\mathrm{p}<0.01 ; * * *$ significant at $\mathrm{p}<0.001$ 


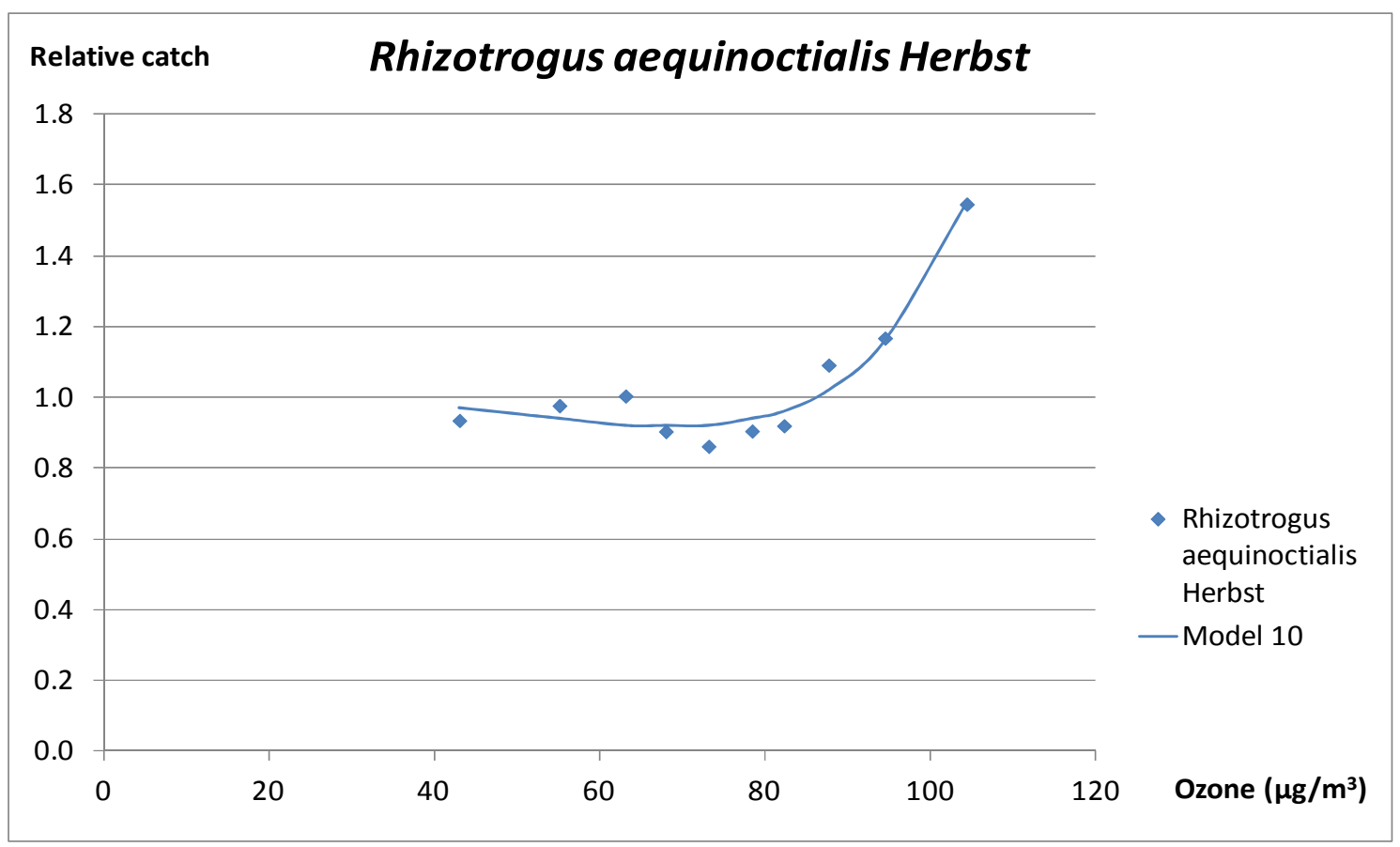

Figure 6. Observed relative catch values and the fitted curve of nonlinear regression model relative to Rhizotrogus aequinoctialis Herbst depending on the ozone content of the air $\left[\mu \mathrm{g} / \mathrm{m}^{3}\right]$ (2004-2011)

We observed the same intensive increase of relative catch values at high ozone content circumstances for Economus tenellus Rambur (Fig. 7). In its transformed saturation model (Model 11) $p_{1}$ is the parameter the fitting curve takes at the right end of the range of the observed ozone content $\left(X=105 \mu \mathrm{g} / \mathrm{m}^{3}\right), p_{2}$ is the parameter which represents the change of the fitting curve values on the whole range of ozone content in the experiment while $p_{3}$ is a velocity factor of the exponential term (Table 7).

Table 7. Nonlinear regression models of the relative catch of Economus tenellus Rambur depending on the ozone content of the air $\left[\mu \mathrm{g} / \mathrm{m}^{3}\right]$ (2001-2005) with their parameter estimates, together with the regression diagnostics( $F$ values of the models, $t$ values of the parameters and the explained variance $R^{2}$ )

\begin{tabular}{|c|c|c|c|c|c|}
\hline Species & $\begin{array}{c}\text { Number of } \\
\text { observation } \\
\text { sites }\end{array}$ & Time & \multicolumn{3}{|c|}{ Model 11} \\
\hline \multirow{5}{*}{$\begin{array}{c}\text { Economus } \\
\text { tenellus } \\
\text { Rambur }\end{array}$} & 5 & $2001-2005$ & \multicolumn{3}{|c|}{$Y=p_{1}+p_{2} *\left(1-\exp \left(-p_{3} *(-X+105)\right)\right)+\varepsilon$} \\
\hline & \multicolumn{2}{|c|}{ Estimated parameters } & $t$ & $F$ & $\mathrm{R}^{2}$ \\
\hline & $p_{1}$ & 2.68 & $29.85 * * *$ & \multirow{3}{*}{$867.15^{* * *}$} & \multirow{3}{*}{$0.98 * * *$} \\
\hline & $p_{2}$ & -1.74 & $-18.87 * * *$ & & \\
\hline & $p_{3}$ & 0.13 & $7.10 * * *$ & & \\
\hline
\end{tabular}

$*$ significant at $\mathrm{p}<0.05 ; * *$ significant at $\mathrm{p}<0.01 ; * * *$ significant at $\mathrm{p}<0.001$ 


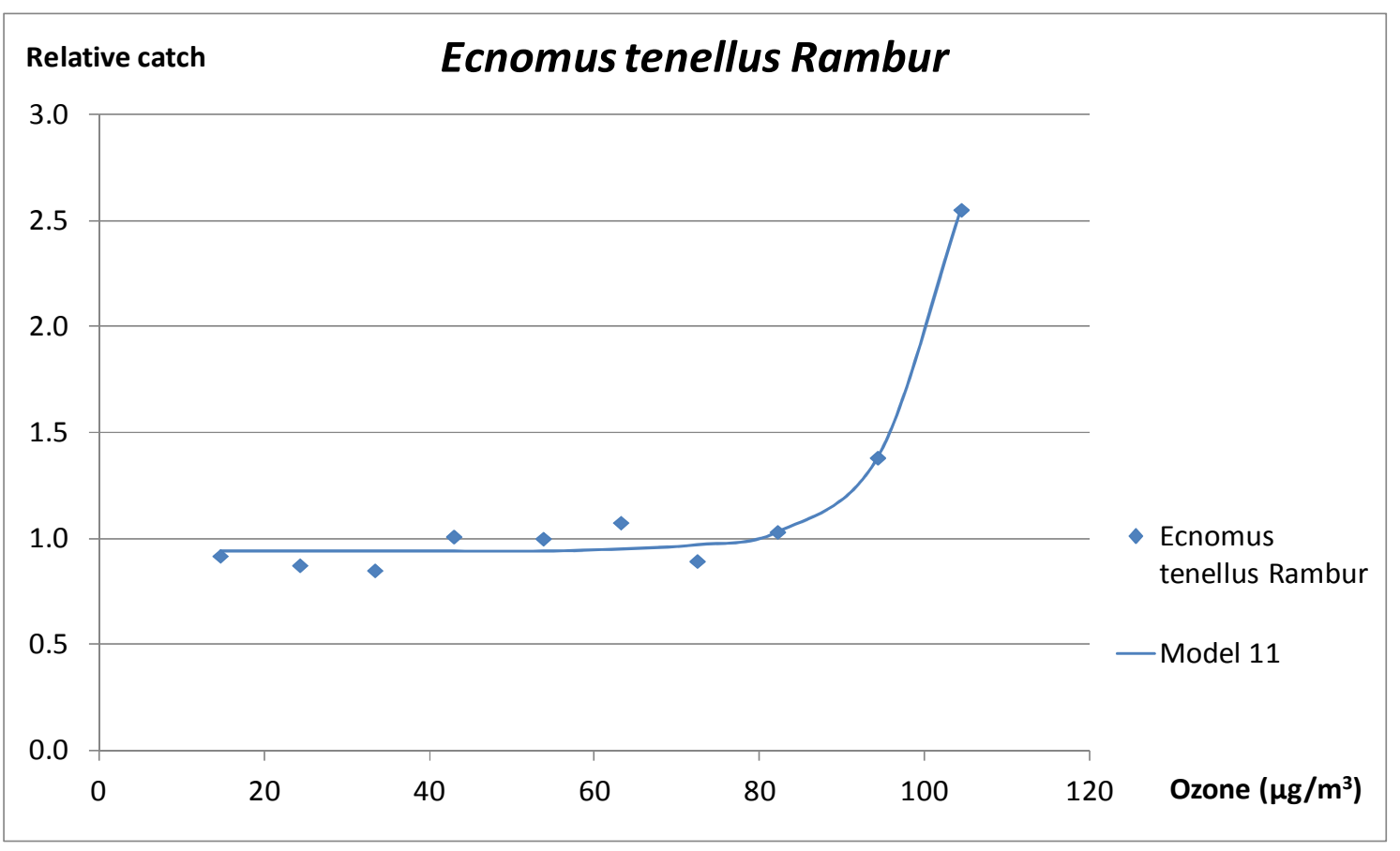

Figure 7. Observed relative catch values and the fitted curve of nonlinear regression model relative to Economus tenellus Rambur depending on the ozone content of the air $\left[\mu \mathrm{g} / \mathrm{m}^{3}\right](2001$ 2005)

According to the calculated determination coefficients, both Model 10 and Model 11 explain more than $90 \%$ of the variance of the observed data and have highly significant $F$ values as well (Table 6, Table 7). By the highly significant $t$ values all the parameter estimates can be judged as reliable.

\section{Discussion}

Our earlier and present results suggest that the flying activity of the European Corn Borer (Ostrinia nubilalis Hbn.), Scarce Bordered Straw (Helicoverpa armigera Hbn), European Vine Moth (Lobesia botrana Den. et Schiff.), Spotted Tentiform Leafminer (Phyllonoricter blancardella Fabr.), Latticed Heath (Chiasmia clathrata L.), April Beetle (Rhizotrogus aequinoctialis Herbst) and Ecnomus tenellus Rambur. increase when the ozone content is high. In case of Hebrew Character (Xestia c-nigrum L.) we detected the increasing flying activity with increasing ozone concentration up to a certain level of ozone concentration which was followed by a decreasing flying activity.

Low relative catch values always refer to environmental factors in which the flight activity of insects diminishes. However, high values are not so clear to interpret. Major environmental changes bring about physiological transformation in the insect organism. The imago is short-lived; therefore unfavourable environmental endangers the survival of not just the individual, but the species as a whole. In our hypothesis, the individual may adopt two kinds of strategies to evade the impacts hindering the normal functioning of its life phenomena. It may either display more liveliness, by increasing the intensity of its flight, copulation and egg-laying activity or take refuge in passivity to environmental factors of an unfavourable situation. By the present state of our 
knowledge we might say that unfavourable environmental factors might be accompanied by both high and low catch (Nowinszky, 2003; Puskás and Nowinszky, 2003).

Each case of the light trapping is unique and unrepeatable and the above results cannot be certificated with laboratory experiments. Therefore, the results of this kind of regularities are difficult to confirm. Laboratory experiments should always be supplemented by field observations because observation results throw new light upon the relation between the ozone in the air and ecosystem.

As the impact of the tropospheric ozone content on the relative catch of the insects is not widely researched field yet, our observations raise several unsolved problems. It need to be clarified whether the main reasons of the examined phenomenon should be searched in the rate of ozone sensitivity of the species, in the current phonological phase of the insects in which the high ozone content is observed, in the length of time of ozone stress or in other species-specific aspects. It is important to investigate the

Ozone content in the troposphere has increased markedly during the past century, mainly because of the release of nitric oxide, carbon monoxide and gaseous hydrocarbons from vehicles and industrial processes and from the burn of biomass in the tropics (Lelieveld et al., 1995). The elevated ozone content in troposphere can cause not only damage to crops and human health but, with interaction of other environmental effects, can also upset the balance of ecosystems. This fact indicates the importance of investigating the impact of elevated tropospheric ozone content on ecosystems, including on the flying activity of insects.

We suggest similar examinations onto other harmful insect species relevantly with other sampling methods (e.g. suction-, Malaise-, bait traps). If it were undoubtedly provable that elevated tropospheric ozone content increases the light-trap catch of certain insect species, it would be necessary to take this fact into consideration when developing the entomological researches and plant protection prognoses, too.

\section{REFERENCES}

[1] Agrell, J., Kopper, B., McDonald, E.P., Lindroth, R.L., (2005): $\mathrm{CO}_{2}$ and $\mathrm{O}_{3}$ effects on host plant preferences of the forest tent caterpillar (Malacosoma disstria). - Global Change Biology 11: 588-599.

[2] Alstad, D.N., Edmunds, G.F., Jr., Weinstein, L.H. (1982): Effects of air pollutants on insect populations. - Annual Review of Entomology 27: 369-384.

[3] Ashmore, M.R., Bell, J.N.B. (1991): The role of ozone in global change. - Ann. Bot. 67 (supp.1): 39-48.

[4] Beard, R.L. (1965): Observation on house flies on high $\square$ ozone environments. - Annual Entomological Society of America 58: 404-405.

[5] Bonjour, E.L., Opit, G.P., Hardin, J., Jones, C.L., Payton, M.E., Beeby, R.L. (2011): Efficacy of ozone fumigation against the major grain pests in stored wheat. - J. Econ. Entomol. 104: 308-316.

[6] Briere, J.F., Pracros, P. (1998): Comparison of temperature-dependent growth models with the development of Lobesia botrana (Lepidoptera: Tortricidae). - Environ. Entomol. 27: 94-101.

[7] Butler, C.D., Beckage, N.E., Trumble, J.T. (2009): Effects of terrestrial pollutants on insect parasitoids. - Environmental Toxicology and Chemistry 28: 1111-1119. 
[8] Dahlsten, D.L., Rowney, D.L., Kickert, R.N. (1997): Effects of oxidant air pollutants on western pine beetle (Coleoptera: Scolytidae) populations in southern California. Environmental Pollution 96: 415-423.

[9] DeLucia, E.H., Dermody, O., O'Neill, B., Aldea, M., Hamilton, J.G., Zangerl, A.R., Rogers, A., Berenbaum, M.R. (2005): Influence of elevated ozone and carbon dioxide on insect densities. - Illittois Crop Protection Techwology Conference, 13-15.

[10] Ferenczi, Z. (2012): Tropospheric ozone measurements at the background monitoring stations of Hungarian Meteorological Service. http://owww.met.hu/en/hmshp.php?almenu id=homepages\&pid=anaten\&pri=5\&mpx $=0$

[11] Freedman, B. (1994): Environmental Ecology: The Ecological Effects of Pollution, Disturbance, and Other Stresses, 2nd (2nd) ed. - Academic, San Diego, CA, USA.

[12] Fuhrer, J. (2003): Agroecosystem responses to combinations of elevated CO2, ozone, and global climate change. - Agriculture, Ecosystems and Environment 97: 1-20.

[13] Gate, I.M., McNeill, S., Ashmore, M.R. (1995): Effects of air pollution on the searching behavior of an insect parasitoid. - Water Air Soil Pollut. 85: 1425-1430.

[14] Graf, W., Murphy, J., Dahl, J., Zamora-Munoz, C., López-Rodríguez, M.J. (2008): Trichoptera. - In: Schmidt-Kloiber, A. and Hering, D. (eds.): Distribution and ecological preferences of European freshwater organisms. 1., Pensoft, Sofia-Moscow.

[15] Grodzki, W., McManus, M., Knízek, M., et al. (2004): Occurrence of spruce bark beetles in forest stands at different levels of air pollution stress. - Environmental Pollution, 130: 73-83.

[16] Hillstrom, M.L., Lindroth, R.L. (2008): Elevated atmospheric carbon dioxide and ozone alter forest insect abundance and community composition. - Insect Conservation and Diversity 1: 233-241.

[17] Holopainen, J.K., Kainulainen, P., Oksanen, J. (1997): Growth and reproduction of aphids and levels of free amino acids in Scots pine and Norway spruce in an open air fumigation with ozone. - Global Change Biology 3: 139-147.

[18] Holton, M.K., Lindroth, R.L., Nordheim, E.V. (2003): Foliar quality influences tree herbivore parasitoid interactions: Effects of elevated $\mathrm{CO}_{2}, \mathrm{O}_{3}$, and plant genotype. Oecologia 137: 233-244.

[19] Inter-Governmental Panel on Climate Change, (2007): Impacts, Adaptation and Vulnerability: Working Group II Contribution to the IPCC. - Fourth Assessment Report: Summary for Policymakers. IPCC Secretariat, Geneva, Switzerland.

[20] Janik, G., Tóth, J., Csóka, Gy., Szabóky, Cs., Hirka, A., Koltay, A. (2008): Az erdészeti jelentőségü cserebogarak életmódja. - Az Erdészeti kutatások digitális, ünnepi különszáma az OEE 139. Vándorgyülésének tiszteletére. Cikkgyüjtemény, pp. 350-380.

[21] Jones, M.E., Paine, T.D., Fenn, M.E., Poth, M.A. (2004): Influence of ozone and nitrogen deposition on bark beetle activity under drought conditions. - Forest Ecology and Management 200: 67-76.

[22] Juhász, Á., Mészáros, R., Szinyei, D., Lagzi, I., Horváth, L. (2006): Evaluation of ozone laden weight based on model calculation (in Hungarian). - Légkör 51: Special Issue 2931.

[23] Kalabokas, P.D. (2002): Rural surface ozone climatology around Athens, Greece. Fresenius Environmental Bulletin 11(8): 474-479.

[24] Kalabokas, P.D., Bartzis, J.G. (1998): Photochemical air pollution characteristics at the station of the NCSR-Demokritos, during the MEDCAPHOT-TRACE campaign in Athens, Greece (20 August-20 September 1994). - Atmospheric Environment, 32(12): 2123-2139.

[25] Kalabokas, P.D., Viras, L.G., Bartzis, J.G., Repapis, Ch.C. (2000): Mediterranean rural ozone characteristics around the urban area of Athens. - Atmospheric Environment, 34: 5199-5208. 
[26] Karnosky, D.F., Skelly, J.M., Percy, K.E., Chappelka, A.H. (2007): Perspectives regarding 50 years of research on effects of tropospheric ozone air pollution on US forests. - Environmental Pollution 147: 489-506.

[27] Kells, S.A., Mason, L.J., Maier, D.E., Woloshuk, Ch.P. (2001): Efficacy and fumigation characteristics of ozone in stored maize. - Journal of Stored Products Research 37(4): 371-382.

[28] Kiss, O., Szentkirályi, F., Schmera, D. (2006): Seasonal swarming activity of caddisflies (Trichoptera) caught by light-traps at different habitats. (in Hungarian). - Acta Biol. Debr. Oecol. Hung. 14: 139-149.

[29] Lelieveld, J., Crutzen, P.J., Jacob, D., Thompson, A. (1995): Modeling of biomass burning influences on tropospheric ozone. - SAFARI BOOK.

[30] Levy, R., Chiu, Y.J., Cromroy, H.L. (1972): Effects of ozone on three species of Diptera. - Environmental Entomology 1: 608-611.

[31] Meleux, F., Solmon, F., Giorgi, F. (2007): Increase in summer European ozone amounts due to climate change. - Atmospheric Environment 41: 7577-7587.

[32] Milonas, P.G., Savopoulou-Soultani, M., Stavridis, D.G. (2001): Day-degree models for predicting the generation time and flight activity of local populations of Lobesia botrana (Den. \& Schiff.) (Lep., Tortricidae) in Greece. - J. Appl. Ent. 125: 515-518.

[33] Mondor, E.B., Tremblay, M.N., Awmack, C.S., Lindroth, R.L. (2004): Divergent pheromone mediated insect behavior under global atmospheric change. - Global Change Biology 10: 1820-1824.

[34] Nógrádi, S., Uherkovich, Á. (2002): Caddisflies in Hungary (Trichoptera) (in Hungarian). - Dunántúli Dolgozatok (A) Természettudományi Sorozat. 11., Baranya megyei Múzeumok Igazgatósága, Pécs, 386.

[35] Nowinszky, L. [ed.] (2003): The Handbook and Light Trapping. - Savaria University Press, 276.

[36] Nowinszky, L., Puskás, J. (2011): Light-trap catch of the harmful insects in connection with the ozone content of the air. - Journal of Advanced Laboratory Research in Biology 2(3): 98-102.

[37] Papanastasiou, D.K., Melas, D., Zerefos, C.F. (2003): Relationship of meteorological variables and pollution with ozone concentrations in an urban area. - 2nd International Conference on Applications of Natural-, Technological- and Economical Sciences, Szombathely (10th May), CD-ROM. pp. 1-8.

[38] Papanastasiou, D.K., Melas, D. (2006): Predicting daily maximum ozone concentration in an urban area. - 4th International Conference on Applications of Natural-, Technologicaland Economical Sciences, Szombathely (28th May), CD-ROM. pp. 1-7.

[39] Papanastasiou, D.K., Melas, D., Zerefos, C.F. (2002): Forecast of ozone levels in the region of Volos. - 6th Hellenic Conference in Meteorology, Climatology and Atmospheric Physics. Ioannina (Grece). Abstracts 79-80.

[40] Peltonen, P.A., Julkunen Tiitto, R., Vapaavuori, E., Holopainen, J.K. (2006): Effects of elevated carbon dioxide and ozone on aphid oviposition preference and birch bud exudate phenolics. - Global Change Biology 12: 670-1679.

[41] Percy, K.E., Awmack, C.S., Lindroth, R.L. et al. (2002): Altered performance of forest pests under atmospheres enriched by $\mathrm{CO}_{2}$ and $\mathrm{O}_{3}$. - Nature 420: 403-407.

[42] Pfeiffer, D.G. Hull, L.A., Biddinger, D.J., Killian, J.C. (1995): Spotted tentiform leafminer, Phyllonorycter blancardella (Fabr.) - In: Hogmire, H.W. (Ed.) Beavers, S.C. Mid-Atlantic Orchard Monitoring Guide. - Natural Resource, Agriculture, and Engineering Service, Cornell University; Ithaca, NY.

[43] Pinto, D.M., Blande, J.D., Nykanen, R., Dong, W.X., Nerg, A.M., Holopainen, J.K. (2007): Ozone degrades common herbivore induced plant volatiles: Does this affect herbivore prey location by predators and parasitoids? - Journal of Chemical Ecology 33: 683-694. 
[44] Pinto, D.M., Himanen, S.J., Nissinen, A., Nerg, A.M., Holopainen, J.K. (2008): Host location behavior of Cotesia plutellae Kurdjumov (Hymenoptera: Braconidae) in ambient and moderately elevated ozone in field conditions. - Environmental Pollution 156: 227231.

[45] Puskás, J., Nowinszky, L. (2010): Flying activity of the Scarce Bordered Straw (Helicoverpa armigera $\mathrm{Hbn}$.) influenced by ozone content of air. - Advances in Bioresearch 1(2): 139-142.

[46] Puskás, J., Nowinszky, L., Károssy, Cs., Tóth, Z., Németh, P. (2001): Relationship between UV-B radiation of the Sun and the light trapping of the European Corn Borer (Ostrinia nubilalis Hbn.) Ultraviolet Ground- and Space-based Measurements, Models and Effects. - Proceedings of SPIE, the International Society for Optical Engineering. San Diego 4482: 363-366.

[47] Qassem, E. (2006): The use of ozone against stored grain pests. - Ninth Arab Congress of Plant Protection, 19-23 November 2006, Damascus, Syria C 5 E-225.

[48] Sáenz-de-Cabezón, F., Maron, V., Zalom, F., Pérez-Moreno, I. (2005): Effects of methoxyfenozide on Lobesia botrana (Den \& Schiff) (Lepidoptera: Torticidae) egg, larval and adult stages. - Pest Manag Sci. 61(11):1133-7.

[49] Stark, R.W., Miller, P.R., Cobb Jr., F.W., Wood, D.L., Parmeter, Jr., J.R. (1968): Incidence of bark beetle infestation in injured trees. - Hilgardia 39: 121-126.

[50] Thompson, R.S., Nelson, B. (2003): The Butterflies and Moths of Northern Ireland. Blackstaff. ISBN-10: 0900761474

[51] Valli, V.J., Callahan, P.S. (1968): The effect of bioclimate on the communication system of night-flying moths. - International Journal of Biometeorology 12(2): 99-118. 